RASĀYAN J. Chem.

Vol. 13 | No. 3 |1792-1800| July - September | 2020

ISSN: 0974-1496 | e-ISSN: 0976-0083 | CODEN: RJCABP

http://www.rasayanjournal.com

http://www.rasayanjournal.co.in

\title{
STUDY OF HEAVY METAL CONTENT (Cd, Cu, Pb, Zn) IN FARMYARD OF LAM DONG PROVINCE, VIETNAM
}

\author{
Quang Hieu Tran ${ }^{1, *}$ and Ngoc Tuan Nguyen ${ }^{2}$ \\ Chemistry Division-Basic Sciences Department-Saigon Technology University, \\ Ho Chi Minh City 700000, Vietnam \\ ${ }^{2}$ Dalat Nuclear Research Institute, VAEI, Vietnam \\ *180 Cao Lo, Ward 4, District 8, Ho Chi Minh City, Vietnam \\ *E-mail: hieu.tranquang@stu.edu.vn
}

\begin{abstract}
This study aimed to evaluate the content of heavy metals, including cadmium, copper, lead, and zinc in 43 cultivated soil samples collected from Hiep An commune, Duc Trong district, Lam Dong province, Vietnam. The levels of these toxic heavy metals in cultivated soils were evaluated as follows: $\mathrm{Cd}(0.16 \mathrm{mg} / \mathrm{kg}$ to $0.64 \mathrm{mg} / \mathrm{kg}), \mathrm{Cu}(9.0 \mathrm{mg} / \mathrm{kg}$ to 41.5 $\mathrm{mg} / \mathrm{kg}), \mathrm{Pb}(17.5 \mathrm{mg} / \mathrm{kg}$ to $41.0 \mathrm{mg} / \mathrm{kg})$ and $\mathrm{Zn}(32.1 \mathrm{mg} / \mathrm{kg}$ to $90.0 \mathrm{mg} / \mathrm{kg})$. The collected data shows that concentrations of heavy metals in the soil samples were below the allowable limit. Therefore, this area is suited to farm vegetables that are the strength of this region, such as salad, cabbage, tomatoes, cauliflower, kohlrabi. Furthermore, this is a good reference for further studies on the content of trace elements, such as heavy metal toxins in the soil or vegetable/crop grown in the area.
\end{abstract}

Keywords: Heavy Metal, Cadmium, Lead, Copper, Zinc, Content.

(C) RASĀYAN. All rights reserved

\section{INTRODUCTION}

In recent years, the ecological and global public health concerns associated with environmental contamination by heavy metals was increased. Besides, human exposure has risen dramatically as a result of an exponential increase in their use in several agricultural, domestic, industrial, and technological applications. Heavy metals could be released to the environment from geogenic, industrial, agricultural, pharmaceutical, domestic effluents, and atmospheric sources have been reported. Environmental pollution is very prominent in point source areas such as mining, factories and smelters, and other metal-based industrial operations. Heavy metals have affected cellular organelles and components such as cell membranes, endoplasmic reticulum, nuclei, and some enzymes involved in metabolism, detoxification, and damage repair. ${ }^{1,2}$ Metal ions have interacted with cell components such as DNA and proteins, causing DNA damage and conformational changes that may lead to cell cycle modulation, carcinogenesis. ${ }^{3-5}$ In recent years, Vietnam has become one of the top countries that produce and export agricultural products in the world. For meeting stringent quality standards from fastidious markets like the US, Japan, and Europe, these products must be controlled from farm factors such as soil quality, water quality, and fertilizer quality and cultivation process. Hiep An commune of Duc Trong district has been selected as one of the strategic areas to grow safe vegetables for domestic and export markets. ${ }^{6}$ However, there is a lack of primary survey data on soil agro-culture in this vegetable growing area, especially trace elements as well as toxic heavy metals.

In this paper, the content of cadmium, copper, lead, and zinc in soil samples in the vegetable growing area was evaluated their content in soils. From this, it was concluded that these soils would be suitable for safe vegetable cultivation.

\section{Instruments and Chemicals}

\section{EXPERIMENTAL}

All used chemicals and solvents were in analytical grade and were used without further purification unless otherwise mentioned. Doubles distilled and degassed water was used throughout, nitric acid $\mathrm{HNO}_{3} 65 \%$, 
RASĀYAN J. Chem.

Vol. 13 | No. 3 |1792-1800| July - September | 2020

$\mathrm{Pb}\left(\mathrm{NO}_{3}\right)_{2}, \mathrm{Cr}\left(\mathrm{NO}_{3}\right)_{3}, \mathrm{Zn}\left(\mathrm{NO}_{3}\right)_{2}, \mathrm{Cu}\left(\mathrm{NO}_{3}\right)_{2}$. Atomic Absorption Spectroscopy with 4 hollow cathode lamps: $\mathrm{Cu}(\lambda=324.64 \mathrm{~nm}) ; \mathrm{Cd}(\lambda=228.7 \mathrm{~nm}) ; \mathrm{Pb}(\lambda=217.0 \mathrm{~nm})$ và $\mathrm{Zn}(\lambda=213.52 \mathrm{~nm})$.

\section{Samples Collection}

The samples were collected twice in 2018 in Hiep An commune, Duc Trong district, Lam Dong province in Fig.-1 as follows:

Phase-1: In the middle of April (dry season) and

Phase-2: In mid-August (rainy season).

Each sample was taken from 2 soil layers, the surface layer $(0-20 \mathrm{~cm})$ and deep layer $(25-50 \mathrm{~cm})$. The weight of each sample is about $0.5 \mathrm{~kg}$. The samples were put into PE bags, sealed and marked with serial numbers, taken to the laboratory in Da Lat Nuclear Research Institute. The soil samples were dried at $105^{\circ} \mathrm{C}$ for 6 hours to obtain the constant weight. The oven-dried material was crushed and sieved through the $2.00 \mathrm{~mm}$ mesh to get a representative sample.

Weighed $0.5 \mathrm{~g}$ of the oven-dried ground sample using a top-loading balance and placed in a $250 \mathrm{~mL}$ beaker, which has been previously washed with nitric acid, and distilled water. The sample was reacted with $5 \mathrm{~mL}$ of $\mathrm{HNO}_{3}, 10 \mathrm{ml}$ of concentrated $\mathrm{H}_{2} \mathrm{SO}_{4}$, and $1 \mathrm{~mL}$ of $\mathrm{HClO}_{4}$ using dropping pipette. The mixture is digested in a fume cupboard, heated further until a dense white smoke appears, let the mixture to cool and diluted with distilled water. The solution is filtered through acid-washed Whatman grade 44 filter paper into a 50 $\mathrm{ml}$ volumetric flask and diluted to mark the volume. The sample solution was aspirated into the Atomic Absorption Spectroscopic instrument to measure the absorption of elements corresponding to their hollow cathode lamps.

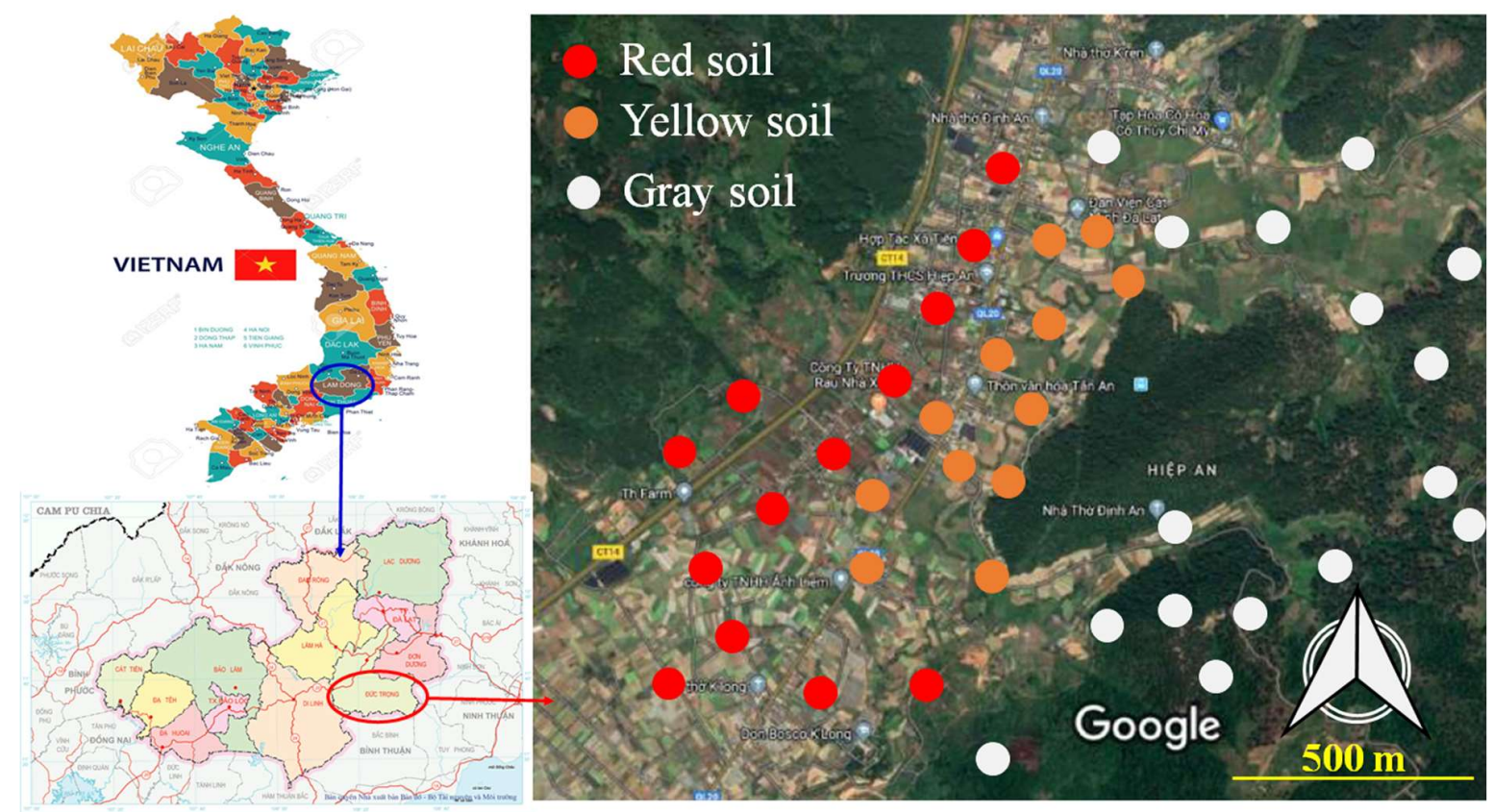

Fig.-1. Sample Collection Map based on Google Maps

\section{Data Analysis}

All data for evaluations were collected from triplicate $(n=3)$ and are presented in average \pm standard deviation (SD).

\section{Accuracy of the Method}

\section{RESULTS AND DISCUSSION}

For testing the accuracy of the method when determining copper, cadmium, lead, and zinc in the study samples, the international standard Soil-7 and Pine-Needles 1575 were selected. Table-1 compares to the recognized values from the international standard samples, and the multi-element standard samples of 
RASĀYAN J. Chem.

Vol. 13 | No. 3 |1792-1800| July - September | 2020

Merck differ only from \pm 5 to $\pm 12 \%$. Hence, the AAS method can be used to determine these metals in real samples.

Table-1: Comparison of Analytical Results and Recognized Values for Standard Samples (ppm)

\begin{tabular}{c|c|c|c|c}
\hline & \multicolumn{2}{|c|}{ Soil-7 $(\mathrm{ppm})$} & \multicolumn{2}{c}{ Pine-Needles 1575 (ppm) } \\
\hline Metal & Recognized values & Found values & Recognized values & Found values \\
\hline $\mathrm{Cd}$ & 1.3 & $1.1 \pm 0.2$ & - & $0.025 \pm 0.003$ \\
\hline $\mathrm{Cu}$ & 11 & $12.4 \pm 1.1$ & $3.0 \pm 0.3$ & $3.1 \pm 0.3$ \\
\hline $\mathrm{Pb}$ & 60 & $56.3 \pm 5.4$ & $10.8 \pm 1.0$ & $11.3 \pm 1.1$ \\
\hline $\mathrm{Zn}$ & 104 & $98 \pm 10$ & $70^{*}$ & $68.9 \pm 7.0$ \\
\hline
\end{tabular}

(*) non-certified (only information)

\section{Evaluation of the Cd content}

Cadmium is one of the heavy toxic metals that seriously affect human health. It may lead to fatality once inhaled or ingested. After poisoning into the human body, symptoms such as abdominal pain, burning sensation, nausea, vomiting, salivation, muscle cramps, vertigo, shock, loss of consciousness and convulsions usually appear in a short time. Gastrointestinal tract erosion, pulmonary, hepatic, or renal injury and coma, depending on the route of poisoning, could be caused by cadmium. Chronic exposure to cadmium has a depressive effect on levels of norepinephrine, serotonin, and acetylcholine. ${ }^{4}$ Cadmium is an element trace in certain foods, such as grains, leafy vegetables, potatoes, seeds, liver, kidney, crustaceans, and mollusks. ${ }^{7} \mathrm{Cd}$ is capable of being absorbed on the biomass of vegetables. ${ }^{8}$ Therefore, the high content of $\mathrm{Cd}$ in the soil causes an increase in the possibility of contamination of this metal into vegetables, resulting in risks to human health.

The results of the analysis of Cd content were presented in Table-2. The cadmium content in the surface layer and deep layer of red soil ranges from $0.38 \mathrm{mg} / \mathrm{kg}$ to $0.64 \mathrm{mg} / \mathrm{kg}$ and from $0.24 \div 0.59 \mathrm{mg} / \mathrm{kg}$. These values in the surface of the red-yellow soil and Gray soil were $0.19 \div 0.37 \mathrm{mg} / \mathrm{kg}$ and $0.16 \div 0.19 \mathrm{mg} / \mathrm{kg}$, whereas the $\mathrm{Cd}$ content in the deep layer of these two soils was $0.15 \div 0.41 \mathrm{mg} / \mathrm{kg}$ and $0.18 \div 0.19 \mathrm{mg} / \mathrm{kg}$, respectively. The $\mathrm{Cd}$ content in the cultivated land at Hiep An commune was below the allowed level set by the Ministry of Science and Technology of Vietnam for vegetable cultivation land $(2 \mathrm{mg} / \mathrm{kg}){ }^{9}$

The pie charts in Fig.-2 and 3 compare the ingredient of $\mathrm{Cd}$ in the surface layer and the deep layer between the dry season and the rainy season. The diagram depicts that the content of $\mathrm{Cd}$ in the surface layer is higher than it is in the deep layer (in both seasons). This phenomenon could be attributed by adding fertilizers, such as Song Danh organic fertilizer $(0.8 \mathrm{mg} \mathrm{Cd} / \mathrm{kg}$ ), Kovac microbial fertilizer $(1.2 \mathrm{mg} \mathrm{Cd} / \mathrm{kg})$, NPK French $(0.2 \mathrm{mg} \mathrm{Cd} / \mathrm{kg})$ and Hanexim Ure $(0.5 \mathrm{mg} \mathrm{Cd} / \mathrm{kg})$. However, the Cd content in the rainy season is less than the dry season. It can be explained that the terrain of this area is relatively steep, causing washing away the elements in the soil.

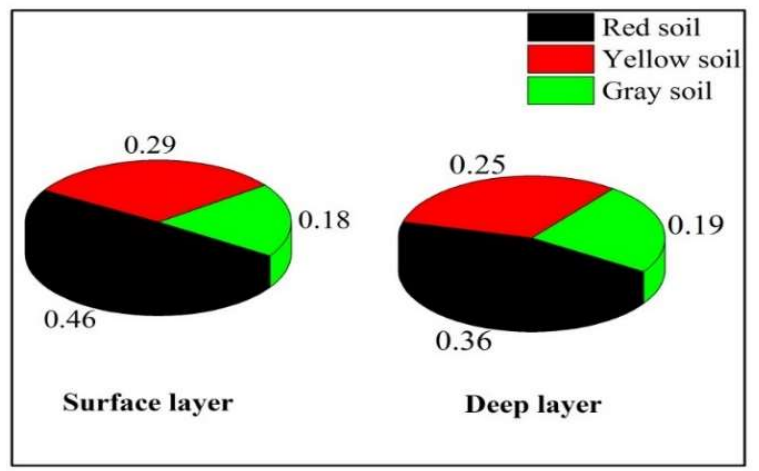

Fig.-2. The Content of Cd (mg/kg) in Different Types of Soil in the Dry Season

Table-2: Cd Content (mg/kg) in Soil

\begin{tabular}{c|c|c|c|c|c}
\hline \multicolumn{2}{c|}{ Type of Soil } & \multicolumn{2}{c|}{ Dry season } & \multicolumn{2}{c}{ Rainy season } \\
\cline { 3 - 6 } \multicolumn{2}{c|}{} & Surface Layer & Deep Layer & Surface Layer & Deep Layer \\
\hline Red Soil & Range & $0.38 \div 0.64$ & $0.24 \div 0.59$ & $0.35 \div 0.53$ & $0.33 \div 0.46$ \\
\hline
\end{tabular}


RASĀYAN J. Chem.

Vol. 13 | No. 3 |1792-1800| July - September | 2020

\begin{tabular}{c|c|c|c|c|c}
\hline & Average & $0.46 \pm 0.09$ & $0.36 \pm 0.13$ & $0.40 \pm 0.06$ & $0.38 \pm 0.05$ \\
\hline \multirow{2}{*}{$\begin{array}{c}\text { Red-Yellow } \\
\text { Soil }\end{array}$} & Range & $0.15 \div 0.41$ & $0.15 \div 0.41$ & $0.15 \div 0.44$ & $0.14 \div 0.39$ \\
\cline { 2 - 6 } & Average & $0.29 \pm 0.07$ & $0.25 \pm 0.10$ & $0.28 \pm 0.11$ & $0.26 \pm 0.09$ \\
\hline \multirow{2}{*}{ Gray Soil } & Range & $0.16 \div 0.19$ & $0.18 \div 0.19$ & $0.18 \div 0.22$ & $0.21 \div 0.22$ \\
\cline { 2 - 6 } & Average & $0.18 \pm 0.01$ & $0.19 \pm 0.01$ & $0.19 \pm 0.02$ & $0.22 \pm 0.01$ \\
\hline
\end{tabular}

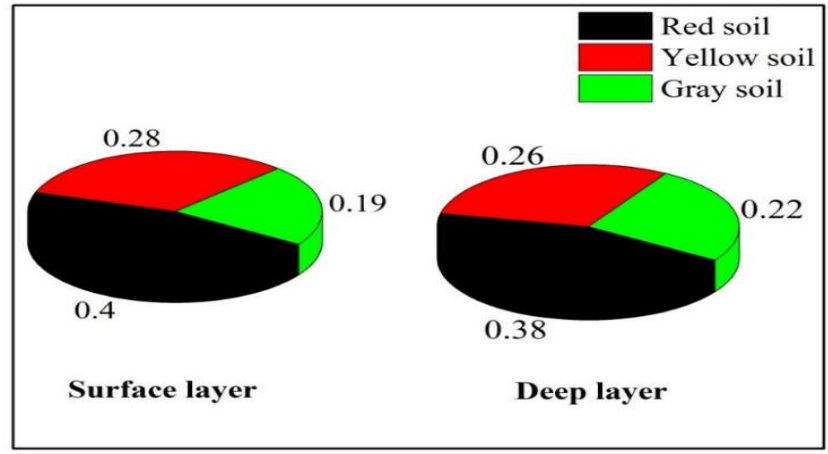

Fig.-3: The Content of Cd $(\mathrm{mg} / \mathrm{kg})$ in Different Types of Soil in the Rainy Season

\section{Evaluation of the Cu Content}

For human life, copper is an essential substance. However, at a high level, it can cause anemia, liver and kidney damage, and stomach and intestinal irritation. Besides, this element can affect on a cycle between $\mathrm{Cu}(\mathrm{II})$, and $\mathrm{Cu}(\mathrm{I})$ in redox reactions of the cuproenzymes. ${ }^{10}$ This property of copper can result in the generation of superoxide and hydroxyl radicals. Also, excessive exposure to copper has been linked to cellular damage leading to Wilson's disease in humans. ${ }^{11}$

Table-3, Fig.-4, and 5 show the $\mathrm{Cu}$ content in the cultivated land of Hiep An Commune. The data would seem to suggest that the $\mathrm{Cu}$ contents in the red soil were higher than Yellow soil and Gray soil in both seasons, in particular about 2.2 times of Yellow soil and range approximately 3.0-4.0 times of Gray ground. Moreover, several noteworthy results were the $\mathrm{Cu}$ content in the surface layer more than the deeper layer. It may be explained that the surface layer is supplemented with copper through fertilizer and pesticides, such as copper sulfate during cultivation. Besides, the obtained $\mathrm{Cu}$ values in soil samples of Hiep An commune were higher than agricultural lands in some other places, for example, Da Lat (surface layer: $15.6 \mathrm{ppm}$, deep layer: 12.6 $\mathrm{mg} / \mathrm{kg}$ ), equivalent to Nha Be agricultural land $(24.6 \mathrm{mg} / \mathrm{kg}$ ) and rubber growing land in Dong Nai province (surface layer $21.6 \mathrm{mg} / \mathrm{kg}$, bottom floor $12.8 \mathrm{mg} / \mathrm{kg}$ ).

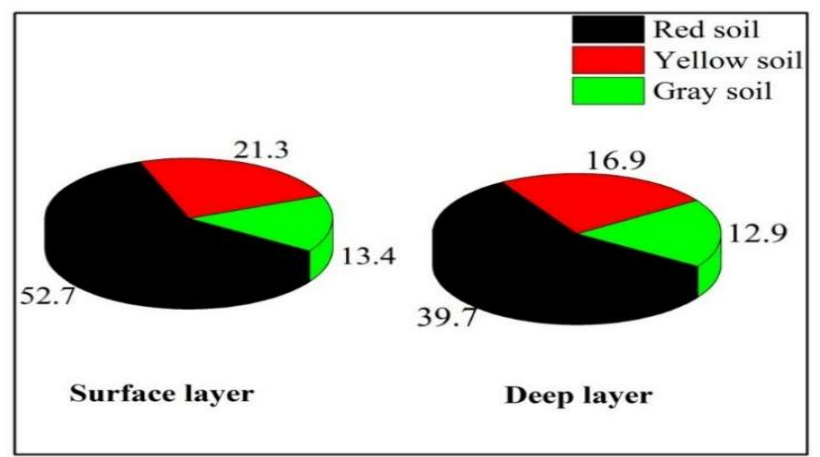

Fig.-4: The Content of $\mathrm{Cu}(\mathrm{mg} / \mathrm{kg})$ in Different Types of Soil in the Dry Season

Nevertheless, the copper content exceeds the allowable limit for vegetable cultivation by the Vietnam Ministry of Science and Technology $(50 \mathrm{mg} / \mathrm{kg})^{9}$. The accumulation of copper in the soil may be due to geological nature or because in the cultivation process, many types of fertilizers, pesticides, copper-containing growth solutions have been used. 
RASĀYAN J. Chem.

Vol. 13 | No. 3 |1792-1800| July - September | 2020

Table-3: Cu Content $(\mathrm{mg} / \mathrm{kg})$ in Soil

\begin{tabular}{c|c|c|c|c|c}
\hline \multicolumn{2}{c}{ Type of Soil } & \multicolumn{2}{c|}{ Dry Season } & \multicolumn{2}{c}{ Rainy Season } \\
\cline { 3 - 6 } \multicolumn{2}{c|}{} & Surface Layer & Deep Layer & Surface Layer & Deep Layer \\
\hline \multirow{2}{*}{ Red soil } & Range & $41.5 \div 66.6$ & $24.6 \div 50.2$ & $42.2 \div 62.2$ & $30.7 \div 51.5$ \\
\cline { 2 - 6 } & Average & $52.7 \pm 9.5$ & $39.7 \pm 6.6$ & $50.3 \pm 7.5$ & $38.4 \pm 7.3$ \\
\hline \multirow{2}{*}{$\begin{array}{c}\text { Red-Yellow } \\
\text { Soil }\end{array}$} & Range & $14.1 \div 31.1$ & $9.3 \div 25.6$ & $9.1 \div 32.9$ & $8.8 \div 24.0$ \\
\cline { 2 - 6 } & Average & $21.3 \pm 5.1$ & $16.9 \pm 4.5$ & $22.0 \pm 6.6$ & $17.2 \pm 4.6$ \\
\hline Gray Soil & Range & $9.0 \div 29.9$ & $8.2 \div 18.2$ & $7.3 \div 13.0$ & $9.6 \div 13.1$ \\
\cline { 2 - 6 } & Average & $13.4 \pm 4.0$ & $12.9 \pm 5.0$ & $10.9 \pm 3.1$ & $11.2 \pm 1.8$ \\
\hline
\end{tabular}

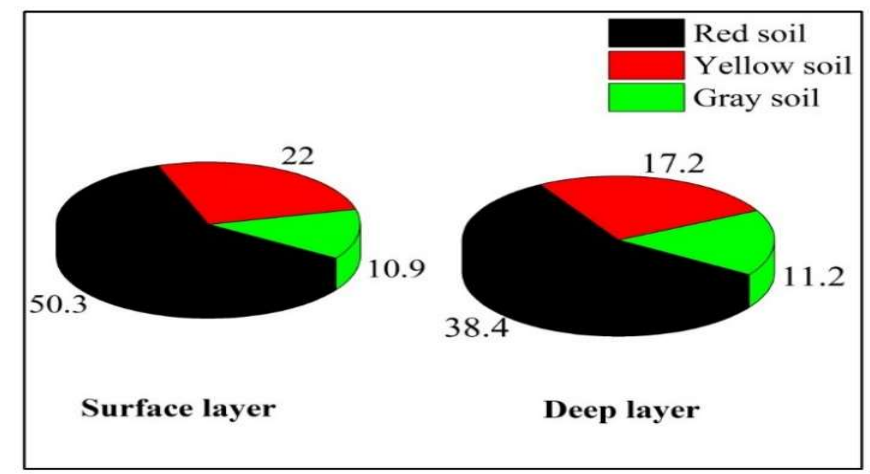

Fig.-5: The Content of $\mathrm{Cu}(\mathrm{mg} / \mathrm{kg})$ in Different Types of Soil in the Rainy Season

\section{Evaluation of the Content of $\mathrm{Pb}$}

Lead is one of the heavy metals with very high toxicity to humans and animals. Lead can inhibit or mimic the actions of calcium and interact with proteins. ${ }^{12}$ Lead is incorporated into the mineral in place of calcium within the skeleton. Binding of biological lead and molecules could form and thereby interfering with their function by several mechanisms. Sulfhydryl and amide groups of enzymes bind with this metal, altering their configuration and diminishing their activities. Lead may also compete with essential metallic cations for binding sites, inhibiting enzyme activity, or changing the transport of essential cations such as calcium. Lead intoxication induces cellular damage mediated by the formation of reactive oxygen species (ROS) that were demonstrated ${ }^{13}$. Also, Jiun and Hsien ${ }^{14}$ reported that the levels of malondialdehyde (MDA) in blood strongly correlate with a lead concentration in the blood of exposed workers. This element affects the activities of antioxidant enzymes, including superoxide dismutase (SOD) glutathione peroxidase. ${ }^{15-17}$ The higher the lead content in the soil, the more ability to contaminate it on the biomass of vegetables. ${ }^{8}$ Therefore, the survey of lead content in soil is very significant. It helps managers to plan growing areas that are suitable for vegetables.

Table-4 presents the results of the analysis of $\mathrm{Pb}$ content in the surface layer and the deep layer in the dry season and the rainy season. When one looks at the statistics, one can see that there is a little bit of $\mathrm{Pb}$ in three types of soil in both seasons. The main reason is that farmers in this commune commonly use fertilizers including $\mathrm{Pb}$, such as Song Danh organic fertilizer $(23.2 \mathrm{mg} / \mathrm{kg}$ ), Kovac microbial fertilizer (17.6 mg/kg), NPK French $(17 \mathrm{mg} / \mathrm{kg})$, and Hanexim Ure $(0.29 \mathrm{mg} / \mathrm{kg})$. Besides, red soil samples that are distributed along Highway 20 may be contaminated with $\mathrm{Pb}$ from the exhaust fumes of vehicles passing through this highway $(\mathrm{Pb}$ was used to be mixed in gasoline to increase octane index before).

Table- 4: The Pb Content in Soil (mg/kg)

\begin{tabular}{|c|c|c|c|c|c|}
\hline \multirow{2}{*}{\multicolumn{2}{|c|}{ Type of Soil }} & \multicolumn{2}{|c|}{ Dry Season } & \multicolumn{2}{|c|}{ Rainy Season } \\
\hline & & Surface Layer & Deep Layer & Surface Layer & Deep Layer \\
\hline \multirow[t]{2}{*}{ Red Soil } & Range & $23.7 \div 32.1$ & $21.1 \div 27.1$ & $17.3 \div 24.3$ & $16.6 \div 26.0$ \\
\hline & Average & $26.8 \pm 3.9$ & $24.5 \pm 2.8$ & $21.2 \pm 2.2$ & $22.6 \pm 3.1$ \\
\hline \multirow[t]{2}{*}{ Yellow Soil } & Range & $20.8 \div 41.0$ & $21.1 \div 40.0$ & $23.5 \div 43.8$ & $22.5 \div 39.1$ \\
\hline & Average & $32.1 \pm 7.0$ & $29.1 \pm 6.1$ & $31.0 \pm 7.0$ & $27.8 \pm 5.6$ \\
\hline \multirow[t]{2}{*}{ Gray Soil } & Range & $17.5 \div 23.2$ & $12.6 \div 19.3$ & $16.0 \div 22.0$ & $11.3 \div 18.8$ \\
\hline & Average & $19.8 \pm 3.0$ & $16.6 \pm 3.5$ & $18.2 \pm 3.3$ & $15.7 \pm 3.9$ \\
\hline
\end{tabular}


RASĀYAN J. Chem.

Vol. 13 | No. 3 |1792-1800| July - September | 2020

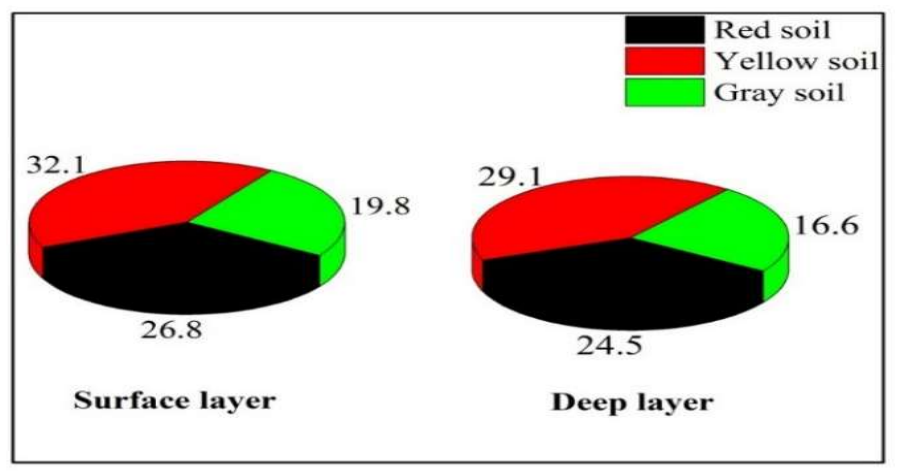

Fig.-6: The Content of $\mathrm{Pb}(\mathrm{mg} / \mathrm{kg})$ in Different Types of Soil in the Dry Season

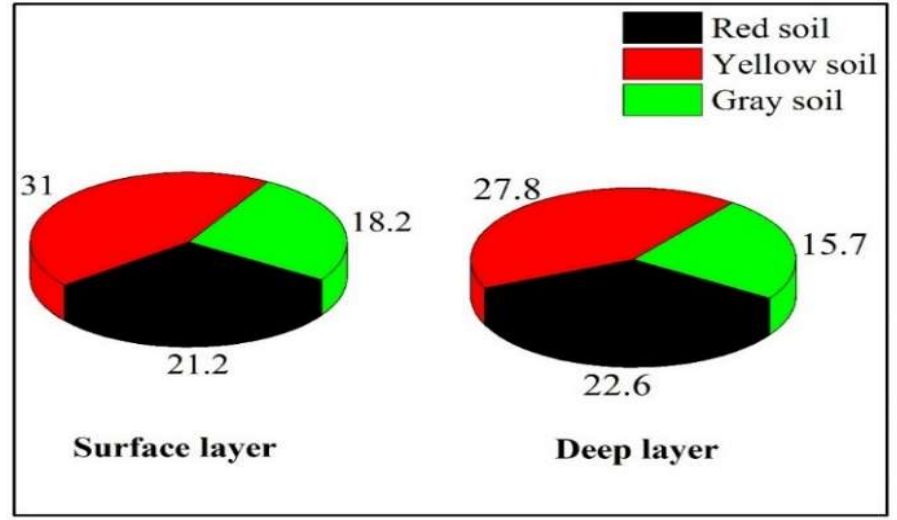

Fig.-7: The Content of $\mathrm{Pb}(\mathrm{mg} / \mathrm{kg})$ in Different Types of Soil in the Rainy Season

From these Fig.-6 and 7, it is apparent that the contents of $\mathrm{Pb}$ in yellow-red soil in both seasons were the highest, followed by red basalt soil, ending with the lowest content of $\mathrm{Pb}$ in Gray soil. However, there is not much difference between the two seasons in the same soil layer. In comparison with the permitted level by the Ministry of Science and Technology of Vietnam $(70 \mathrm{mg} / \mathrm{kg}$ ) for the cultivated land, it can conclude that these $\mathrm{Pb}$ contents are safe for vegetables. ${ }^{9}$

\section{Evaluation of the Zn Content}

Zinc is a non-toxic element to animals and humans, which is proved by the LD50 of the sulfate salts in rats. The oral LD50 for zinc is close to $3 \mathrm{~g} / \mathrm{kg}$ body weight according to the Toxnet database of the U.S. National Library of Medicine. Besides, an important factor seems to be zinc homeostasis, allowing the efficient handling of an excess of orally ingested zinc, because, after intraperitoneal injection into mice, the LD50 for zinc was only approximately four-fold higher than for cadmium and mercury. The role of zinc in biology can be grouped into three general functional classes, namely catalytic, structural, and regulatory functions. ${ }^{18}$ Zinc content in soil is also an indicator to determine soil quality. ${ }^{19,20}$ If the zinc content is high, plants could easily absorb and grow well. In contrast, plants will grow poorly when the zinc level is low. The results of the analysis of $\mathrm{Zn}$ content is presented in Table-5, Fig.-8, and 9.

With red soil in the dry season, the $\mathrm{Zn}$ content of the surface layer fluctuates in the range of $62.2 \mathrm{mg} / \mathrm{kg}$ to 92.5 $\mathrm{mg} / \mathrm{kg}$; the average value is $80.8 \mathrm{mg} / \mathrm{kg}$. At the bottom layer, the $\mathrm{Zn}$ content ranges from 47.6 to $82.5 \mathrm{mg} / \mathrm{kg}$, an average of $61.2 \mathrm{mg} / \mathrm{kg}$. This value in the rainy season was as follows: surface layer 63.8 to $84.4 \mathrm{mg} / \mathrm{kg}$, an average of $74.0 \mathrm{mg} / \mathrm{kg}$; in the deep layer, 49.3 to $83.5 \mathrm{mg} / \mathrm{kg}$. Zinc is one of the essential trace elements for plants. The high $\mathrm{Zn}$ content proves that soil is suitable for many crops, including leafy vegetables and root crops. The zinc content of the red soil samples is the highest, followed by the red and yellow soil, the lowest in the gray soil. The results of this analysis also showed conformity with the regulations by the Vietnamese Ministry of Science and Technology for vegetable land. 
RASĀYAN J. Chem.

Vol. 13 | No. 3 |1792-1800| July - September | 2020

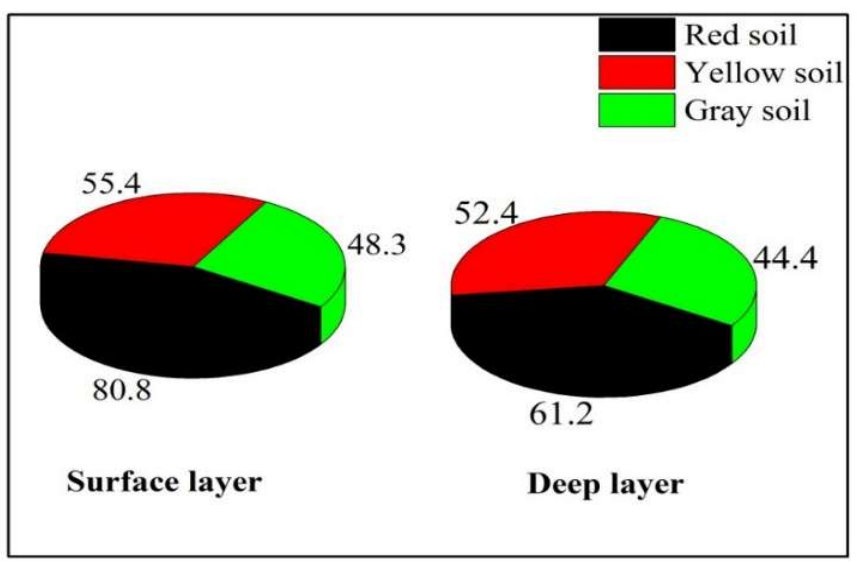

Fig.-8: The Content of $\mathrm{Zn}(\mathrm{mg} / \mathrm{kg})$ in Different Types of Soil in the Dry Season

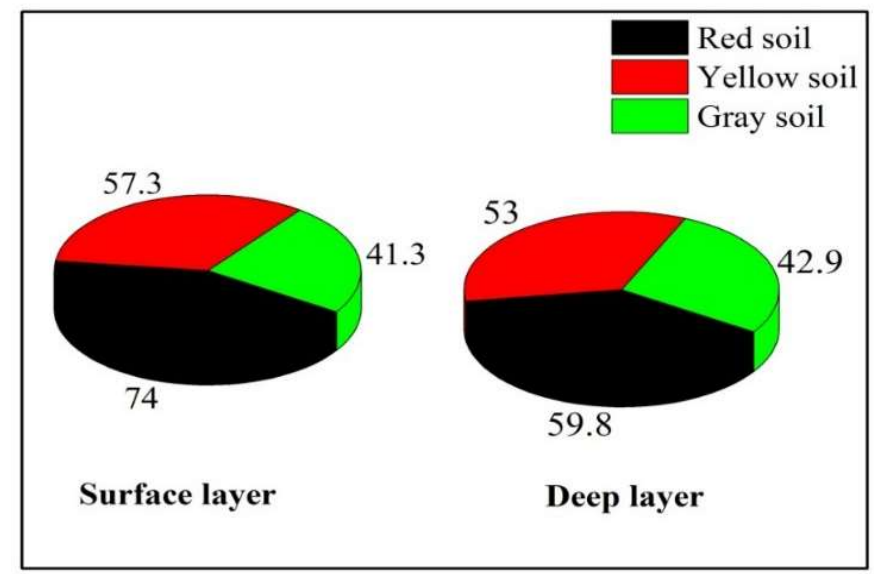

Fig.-9: The Content of Zn ( $\mathrm{mg} / \mathrm{kg})$ in Different Types of Soil in the Rainy Season

\section{Comparison of the Content of These Toxic Heavy Metals in Soil}

Figure-10 compares the contents of $\mathrm{Cd}, \mathrm{Cu}, \mathrm{Pb}, \mathrm{Zn}$ in the surface layer of cultivated land at Hiep An commune, Lamdong province, Vietnam. Overall, the $\mathrm{Zn}$ content in the Red soil is the highest, and the Cd content in the Gray soil is the lowest in both dry and rainy seasons. Some reasons can illuminate these: firstly, the nature of Red soil has the concentration of these metal more than others; secondly, this land has been used to cultivate. Thus a lot of fertilizers are used, resulting in the most accumulation of heavy metals. Therefore, some solutions proposed to protect these cultivated land are to plant a variety of vegetables that are suitable for different soils and to reduce the fertilizers, which are harmful to these areas.

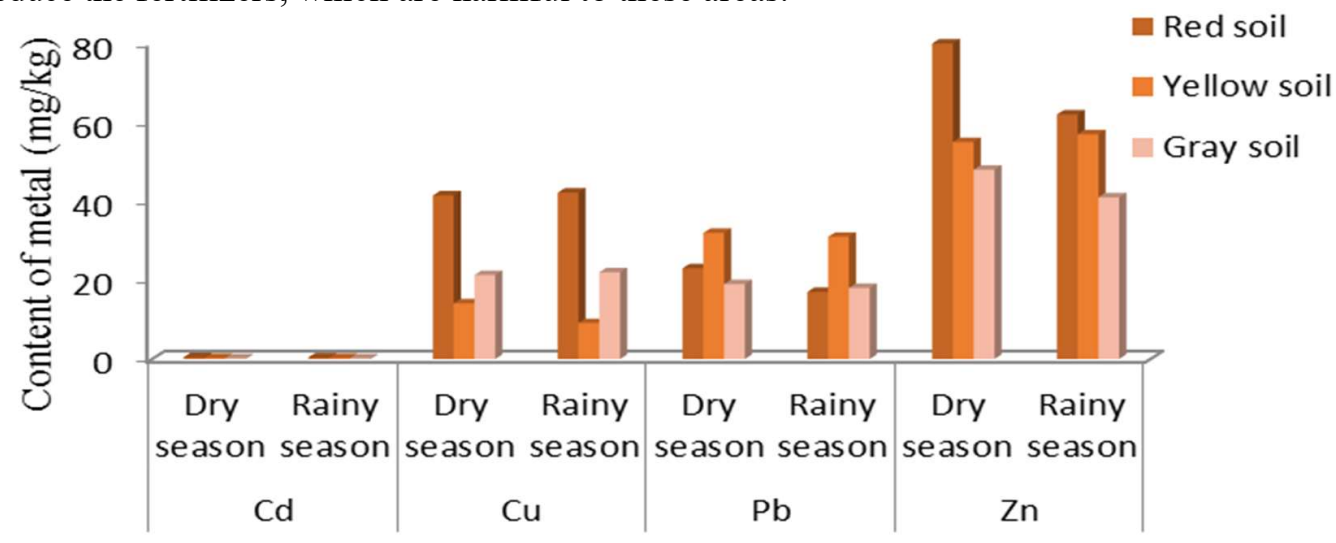

Fig.-10: Graph of Content Distribution of Metals in the Surface Layer (mg/kg). 
RASĀYAN J. Chem.

Vol. 13 | No. 3 |1792-1800| July - September | 2020

Table-5: The Zn Content in Soil (mg/kg)

\begin{tabular}{|c|c|c|c|c|c|}
\hline \multirow{2}{*}{\multicolumn{2}{|c|}{ Type of Soil }} & \multicolumn{2}{|c|}{ Dry season } & \multicolumn{2}{|c|}{ Rainy Season } \\
\hline & & Surface Layer & Deep Layer & Surface Layer & Deep Layer \\
\hline \multirow[t]{2}{*}{ Red Soil } & Range & $62.2 \div 92.5$ & $47.6 \div 82.5$ & $63.8 \div 84.4$ & $49.3 \div 83.5$ \\
\hline & Average & $80.8 \pm 11.3$ & $61.2 \pm 13.9$ & $74.0 \pm 7.7$ & $59.8 \pm 12.4$ \\
\hline \multirow[t]{2}{*}{ Yellow Soil } & Range & $42.7 \div 80.2$ & $34.2 \div 77.7$ & $35.6 \div 75.6$ & $34.1 \div 69.1$ \\
\hline & Average & $55.4 \pm 12.9$ & $52.4 \pm 14.9$ & $57.3 \pm 12.9$ & $53.0 \pm 11.1$ \\
\hline \multirow[t]{2}{*}{ Gray Soil } & Range & $32.6 \div 59.7$ & $29.6 \div 58.0$ & $30.2 \div 53.1$ & $28.2 \div 54.7$ \\
\hline & Average & $48.3 \pm 14.1$ & $44.4 \pm 14.2$ & $41.3 \pm 11.5$ & $42.9 \pm 13.5$ \\
\hline
\end{tabular}

\section{CONCLUSION}

The content of heavy metal elements $(\mathrm{Cd}, \mathrm{Cu}, \mathrm{Pb}$, and $\mathrm{Zn})$ in 43 cultivated soil areas in two seasons has been surveyed to represent the three main types of soil in Hiep An Commune. The content of heavy metals in the soil is still within the allowable limits for vegetable land by the Ministry of Science and Technology of Vietnam. The Copper content in several samples of basalt is slightly higher than the permissible limit for growing vegetables that may be due to the use of copper-containing fertilizers. The $\mathrm{Pb}$ content in soil samples along National Highway 20 is higher than in uncultivated land and other types of property. The obtained results will be a useful reference for the authorities to assess and plan a safe vegetable development strategy for Lam Dong province in general and Hiep An in particular.

\section{REFERENCES}

1. Z. L. He, X. E. Yang and P. J. Stoffella, Journal of Trace Elements in Medicine and Biology, 19(2), 125(2005), DOI: 10.1016/j.jtemb.2005.02.010

2. P. B. Tchounwou, C. G. Yedjou, A. K. Patlolla and D. J. Sutton, Experientia supplementum, 101,133(2012), DOI:10.1007/978-3-7643-8340-4_6

3. D. Beyersmann and A. Hartwig, Archives of Toxicology, 82(8), 493(2008), DOI:10.1007/s00204-0080313-y

4. Q. Y. Chen, T. DesMarais and M. Costa, Annual Review of Pharmacology and Toxicology, 59(1), 537(2019), DOI:10.1146/annurev-pharmtox-010818-021031

5. S. Wang, and X. Shi, Molecular and Cellular Biochemistry, 222(1), 3(2001), DOI: $10.1023 / \mathrm{A}: 1017918013293$

6. Duc Trong District People's Committee, Planning of Land Using Hiep An commune, 2000-2010, Department of Science and Technology of Lam Dong, 20-23. (2004).

7. S. Satarug, J. R. Baker, S. Urbenjapol, M. Haswell-Elkins, P. E. Reilly, D. J. Williams and M. R. Moore, Toxicology Letters, 137(1-2), 65(2003), DOI:10.1016/s0378-4274(02)00381-8

8. N. N.Tuan, L. T. T. Tran, N. H. Phuong, and T. M. Tri, Journal of Chemistry, Physics and Biology Analysis, 2, 9(2014).

9. Soil Quality - Maximum Permissible Limits of Heavy Metals in Soil - TCVN-7209:2002 - Ministry of Science and Technology, Vietnam, (2002)

10. B. R. Stern, Journal of Toxicology and Environmental Health, Part A, 73(2-3),114(2010), DOI: $10.1080 / 15287390903337100$

11. L.M. Gaetke, H. S. Chow-Johnson, and C. K. Chow, Archives of Toxicology, 88(11), 1929(2014), DOI: $10.1007 / \mathrm{s} 00204-014-1355-\mathrm{y}$

12. S. J. S. Flora, S. J. S. Flora, G. Saxena, P. Gautam, P. Kaur, and K. D. Gill, Chemico-biological Interactions, 170(3), 209(2007), DOI:10.1016/j.cbi.2007.08.003

13. H.P. Monteiro, E.J. Bechara, D.S. Abdalla, Molecular and Cellular Biochemistry, 103(1), 73(1991), DOI: $10.1007 / \mathrm{bf00229595}$

14. Y. S. Jiun, and L. T. Hsien, Archives of Environmental Health: An International Journal, 49(4), 256(1994), DOI: 10.1080/00039896.1994.9937476

15. A. Kasperczyk, G. Machnik, M. Dobrakowski, D.Sypniewski, E. Birkner, S.Kasperczyk, Toxicology, 301(1-3),79(2012), DOI: 10.1016/j.tox.2012.07.002 
RASĀYAN J. Chem.

Vol. 13 | No. 3 |1792-1800| July - September | 2020

16. M. Dobrakowski, N. Pawlas, A. Kasperczyk, A. Kozłowska, E. Olewińska, A. Machoń-Grecka, S. Kasperczyk, Human \& Experimental Toxicology, 36(7),744(2017), DOI:10.1177/0960327116665674

17. M. Dobrakowski, N. Pawlas, E. Hudziec, A. Kozłowska, A. Mikołajczyk, E. Birkner, S. Kasperczyk, Environ Toxicol Pharmacol. 45, 235(2016), DOI:10.1016/j.etap.2016.06.008

18. N. Roohani, R. Hurrell, R. Kelishadi and R. Schulin, Journal of Research in Medical Sciences: The Official Journal of Isfahan University of Medical Sciences, 18(2), 144(2013)

19. A. R. Henriques, A. Chalfun-Junior, M. Aarts, Brazilian Journal of Plant Physiology, 24(1), 2012, DOI: $10.1590 / \mathrm{S} 1677-04202012000100002$

20. E. J.B.N. Cardoso, R. L. F. Vasconcellos, D. Bini, M. Y. H. Miyauchi, C. A.dos Santos, P. R. L. Alves, A. M. Paula, A. S. Nakatani, J. D. M. Pereira, and M. A.Nogueira, Scientia Agricola, 70(4), (2013), DOI: $10.1590 / \mathrm{S} 0103-90162013000400009$.

[RJC-5360/2020] 